\title{
The Peasants during the Mamlūk Period: How They Have Struggled
}

\author{
By Wan Kamal Mujani* \\ Stuart Borsch ${ }^{\dagger}$
}

Al-Maqrīzi (d.1442) (1940) mentions that maltreatment of the peasants affected farming areas and arable lands. Agricultural activities were sometimes discontinued and productivity impaired because some peasants fled from the villages. Muhammad bin Muhammad bin Khalīl al-Asadī (last known biographical date: 1451) (1968) also says that the oppression of the peasants was another circumstance that affected the agricultural sector in Egypt. Thus, the aim of this article is to discuss the hardships faced by the peasants in Egypt during the Mamlūk era with a special reference to the period of 1468-1517. Among the difficulties suffered by the peasants at that time that affected their lives and agricultural production were the problems in the Iqta $\bar{a}$ ' (fief) system and in irrigation, the lack of technological innovation in agriculture and disturbances caused by climatic and biological disasters.

Keywords: agriculture, hardship, Mamlūk, peasant, struggle.

\section{Introduction}

The peasants formed the majority of inhabitants in Egypt and lived in the villages and the countryside within the area belonging to the Iqtâa ' holder they served. Their cottages were built of mud and draft animals lived with them in a corner of the same cottage. Their clothes were woven by hand from cotton and wool. Indeed, for the most part the peasant class lived in deprivation and misery (Ibn Tuūūn 1973). They depended on the Nile flood to irrigate the cultivatable areas because of the dry climate and A low water level meant that all potentially cultivatable areas would not be irrigated and consequently the size of the ensuing crop would not meet annual requirements. A sharp increase in grain prices would occur as a consequence and this would continue until the next satisfactory crop was harvested (Al-Nuwayrī 1931). ${ }^{1}$

\footnotetext{
*Lecturer \& Dean, National University of Malaysia, Malaysia.

${ }^{\dagger}$ Professor, Assumption College, USA.

${ }^{1}$ The situation was at its worst when the flood did not exceed twelve cubits because this meant famine
} 
The same result would occur when the Nile flood was too high. Some areas would become submerged under lakes and the time for sowing would pass without this taking place. Al-Maqrīzi (1998) explains that if the level of the Nile is seventeen cubits and above, Ghalā' (high prices) would follow and would destroy the people. Similarly, if the flooding were to be delayed, a sharp increase in the price of grain would also ensue. However, prices would gradually fall after the Nile reached its full level.

During the Mamlūk period, the peasants had a good understanding of how to maintain the quality of the soil, a knowledge passed down from pre-Islamic times. Thus, for example, they were aware of the necessity of crop rotation in order to avoid exhausting the soil, and they therefore let part of the land lie unplanted in order to renew its fertility. Such techniques continue in use to this day. According to Al-Maqrīzī (1998), the cultivated and uncultivated lands in Egypt could be classified into a certain number of categories designated by technical names. Some of these technical names are still used by modern Egyptian peasants.

\section{The Peasants And Agricultural Practice}

The system of cultivation in the Mamlūk period showed historical continuity from earlier times. Thus, the peasants inherited the agricultural calendar from their pre-Islamic predecessors. The times of sowing and harvesting of various kinds of crops were fixed according to the Coptic solar year. Al-Maqrīzī (1998) and other historians mention the types of crops which were cultivated and harvested during each particular Coptic month, as well as the time to plough, irrigate, fertilise, weed and so on (Al-Makhzūmī 1986).

The Nile flood would cover the land to a level of one and a half metres for about forty-five days. As soon as the water receded, it was possible for the peasants to walk across the soil and to begin cultivation. The crops which were cultivated at this time did not need any irrigation other than the flood. They were winter crops.

After the soil had been ploughed or tilled, the peasants would occasionally drive sheep over the freshly sown fields so as to force the seeds down into the hard mud. Under the Mamlūks, the peasant received his seeds for cultivation from the Muqtâa' . Normally, the sulțān would supply the seeds to the Muqtạa at the same time as the conferment of Iqtāa ${ }^{\prime}$. In addition to the technique of crop rotation, the peasants also maintained the fertility of the soil with compost made from such as animal waste or rubbish heaps. Indeed, these latter were a frequent source of fertilizer providing nitrogen in the equivalent of $2-3 \%$ nitrate of soda (Cooper 1977).

When the plants started to grow the peasants had to pull out the weeds. This work was very important for productive agriculture. When the harvest season arrived, the peasants used a short sickle to cut their crops. In the threshing activity to separate the grain, cows and bulls were driven round the threshing floor in a circle and their hooves would tread the grain. After 
threshing came the winnowing to remove the chaff from the grain. For this, the peasants would use a wooden winnowing fork or occasionally two small bent boards to aerate the grain which then fell straight down while the chaff was blown aside. The grain was passed through a coarse sieve to separate it from the worst chaff and dirt. Following this, it was loaded on donkeys or camels and taken to the Nile from where it was transported by the sultān's fleets or by commercial vessels to the warehouses and granaries in Fusțāt and Cairo (Rabie 1981).

\section{The Peasants and the IqṬā' System}

Under the Iqțā' system, the Egyptian peasant was a slave to the Muqtāa . This is the reason why the term Qinn (serf) is used in the Mamlūk sources to describe the peasants. Elsewhere, Al-Nuwayrī (1931) uses the term Fallāhīn alqarāriyya (the peasants for forever) to designate them, which indicates the fact that they had to remain in the village until death. This applied not only to the peasant but also to his sons. He could only leave his village with the permission of the Muqtāa', and then only for a specific time. Otherwise, the Muqtāa could bring him back with the assistance of the authorities, and was even obliged by them to do so. The Muqtâa could punish his peasants with flogging and imprisonment, and sometimes even put them to death. He was entitled to decide civil lawsuits among his peasants if the suitors preferred him to the Qầīi (judge) or to an arbiter. Conversely, the peasant could not submit a complaint against his Muqtâa ' to the legal or administrative authorities.

In the Iqtâa system, the peasant paid the Muqtâa rent for the cultivated land or alternatively a fixed share (Muqāsama) of the produce. ${ }^{1}$ Rents varied according to the type of soil and the method of irrigation and were at the discretion of the Muqtāa . The rent per Faddān ${ }^{2}$ of cultivated land at the end of the fourteenth century was as follows:

i) The rent for the $\mathrm{Băq}^{3}$ soil was about forty Dirhams. It subsequently increased to more than 100 Dirhams.

ii) The rent for Barāyib ${ }^{1}$ soil was thirty Dirhams and then increased to eighty Dirhams.

\footnotetext{
${ }^{1}$ Relations between the Iqțā holders and the peasants were formalized through Qabāla contracts. According to this arrangement, the former allocated land and lent seed to the latter. The Iqtạa ' holders also employed private agents (Mubāshirūn) to collect taxes and distribute the seed.

${ }^{2}$ The size of a medieval Faddān was 5,900 square metres. This surface measure varied until Muhammad 'Alī who fixed it at 4,416.53 square metres. However, the Faddān now measures 4,200 square metres, or 1.038 acres.

${ }^{3}$ The soil which was cultivated in the previous year with Qurt (clover) and Maqātī (various gourds) was the most fertile and the highest in value and tax rate. This was because the previous crops produced nitrogen which made the land fertile. Furthermore, the land could subsequently be cultivated with wheat and flax.
} 
However, at the beginning of the fifteenth century, the rent per Faddān of many lands increased sharply by between 300 to 600 Dirhams.

On the fixed share of the produce, which depended on the fertility of the land and kind of crop, the peasant took one sixth, one fifth, one quarter, one third or one half. The size of this fixed share was at the discretion of the Muqtạ̄a (Al-Ṭurkhān 1968).

Mamlūk sources mention that the peasants were always oppressed by the Muqtā ${ }^{-}$and were allowed to keep only an insufficient proportion of their produce and had to pay high rents. The peasants usually had to rely on the Muqtạa ${ }^{-}$to provide them with them seed and the means of livelihood and were therefore heavily indebted to them. In the later Mamlūk period, the burden of falling agricultural revenues was shifted to the peasantry in the form of higher taxes, higher interest rates for the loan of grain and extraordinary payments. ${ }^{2}$

Some examples of onerous legal taxes (Mukūs) imposed on the peasants are Muqarrar al-jusūr (dams tax), ${ }^{3}$ Muqarrar al-jarārîf wa-l-hafāà ir (digging tool $\operatorname{tax})^{4}$ Maks al-mașāyid (fishing tax), ${ }^{5}$ Maks 'adād al-marā' $\overline{1}$ (livestock tax), ${ }^{6}$ Maks masāhat al-qașab wa-l-qulqās (sugar-cane and colocasia tax), ${ }^{7}$ Maks alfawākih (fruit tax) ${ }^{8}$ Maks al-ḥashīsh (cannabis tax) ${ }^{9}$ and Darība al-qudūm (arrival tax). In addition, the peasants had to provide Hadāya ${ }^{10}$ (presents or gifts) to the officials of the government bureaux (Dawāwīn). ${ }^{11}$ They also had to cover the expenses of the Shädd (military associate) when he came to the village to collect the taxes. Sometimes they were ordered to provide fodder for the horses belonging to the Mamālik al-sultāniyya (The royal Mamlūks).

Occasionally, the sulțāns ordered the peasants to provide for their needs. For example, Sultān al-Ashraf Sha'bān ordered them to supply him with camels and wheat when he went on a pilgrimage. During Sultān al-Ashraf

\footnotetext{
${ }^{1}$ This soil had been cultivated with wheat and barley in the previous year. Because these two crops had weakened the soil, it was rated below Bāq soil. Clover, Qatțānī (legumes), and various gourds were suitable for cultivation on it to allow it to rest.

${ }^{2}$ When the government's control over the Muqtạ̄ lessened, the latter increased taxes without regard to the changing conditions of cultivation.

${ }^{3}$ This tax was used to finance the construction and maintenance of the irrigation system. This tax was levied on the inhabitants of the districts where irrigation dams needed improvement or reconstruction.

${ }^{4}$ This tax was imposed to finance additional projects for the maintenance of the dams and canals. It was payable in kind, that is, by supplying beasts of burden and harrows. Later the inhabitants of the districts concerned were given the option of paying the tax in cash.

${ }^{5}$ This tax was imposed on for fishing in the canals.

${ }^{6}$ The tax imposed on livestock which were bred on land not reached by the Nile. There was also Muqarrar al-jawāmīs (buffalo tax) where the peasants were forced to pay between three and five Dīnārs for each buffalo they had.

${ }^{7}$ This tax was imposed on sugar-cane and colocasia antiquorum. The amount was based on the width of land cultivated with those crops.

${ }^{8}$ The tax imposed on the various kinds of fruits grown by the peasants.

${ }^{9}$ This tax was imposed on the cultivation of cannabis.

${ }^{10}$ The Hadāyā should be provided every year by the peasants in kind. Some items which were included as gifts were lambs and chickens.

${ }^{11}$ This duty was known as Diyāfāt (guests). The Shādd or Mushidd was a military associate who gave support to the local staff in their collection of taxes.
} 
Qāytbāy's visits to the rural areas in 1468 and 1477, the peasants were ordered to pay an additional tax to him. The peasants were required to pay the same tax during Sulțān Qānșūh al-Ghawrī’s visit to the countryside in 1513. On another occasion, in 1509 Sulțān Qānșūh al-Ghawrī ordered them to cover the expenses of the Ottoman Amīr Yazīd bin Muḥammad bin Murād bin 'Uthmān during his stay in Egypt (Ibn Iyās 1960).

In addition to the above, the amīrs and Julbān (the Mamlūks of the ruling sultan) are said to have raided property that belonged to the peasants, such as harvested crops and livestock. ${ }^{1}$ It is also reported that the amīrs sometimes kidnapped the peasants and held them to ransom. ${ }^{2}$

The period under discussion was also subject to the impact of the changes in the Iqtāa system in Egypt. The abolition of the hereditary character of the Iqtāa ' forced a number of Muqtāa 's to abandon their agricultural lands or at least to make no effort to maintain them. This was simply because the land could not be transferred to their heirs. Moreover, the Muqtā's were only concerned to get as much revenue as they could while still in possession of their Iqțā (Nasir 2003). Thus, in order to obtain the maximum revenue they imposed high taxes on the peasants. In this environment, the peasants could not be productive labourers and some of them fled.

\section{The Peasants and the Irrigation System}

As a result of the crucial importance of the irrigation system to the economic life of Egypt, since Pharaonic times until the medieval period and even today its administration and maintenance have been the responsibility of the state. During the Mamlūk period, these tasks were one of the primary duties of the sultâns and Iqțā' holders. Every Muqțā was responsible for the upkeep of the Jusūr al-baladiyya within the confines of his Iqțā'. They used their own money from the revenue of the Iqtāa to maintain the dams. Usually the peasants who worked in their Iqțā would help them in the construction or repair of the dams. For the Jusūr al-sultāniyya, the sulțāns were responsible for the care of the dam and it was put under the supervision of the Dīwān al-sultān. Nevertheless, in practice, the Muqtạ̄ assisted the sultān in the construction of this type of dam by supplying peasants, oxen, harrows and other tools (AlQalqashandi 1987).

During the period under consideration Mamluk chroniclers make a few remarks about the restoration of dykes and bridges by the government (Ibn Taghrī Birdī 1932). Sometimes, the work of maintenance and repair could not be done on time because the allocation to cover the costs was not enough. Consequently, the peasants could not enjoy the benefits of the irrigation system

\footnotetext{
${ }^{1}$ For instance, in 1496 and 1511 al-Dawādār Ṭūmānbāy confiscated livestock belonging to the peasants in the rural areas.

${ }^{2}$ Ibn Iyās (1960) reports that amīrs during Sulțān Qānșūh al-Ghawrī’s reign kidnapped the female members of peasant families in order to force them to pay their taxes.
} 
The Mamlūk sources also reveal that the costs were imposed on the people. For instance, when the dam in Fayyūm was damaged in 1512, the sultạn required the peasants and the Iqtāa holders to cover the expenses of repairing it. Amīr Arzamak al-Nāshif, who was responsible for supervising the work, took the cost from the revenue of their Iqțā 's. Shortly before this event, the sulțān ordered the Iqțā' holders in Jizza province to pay for maintaining the Umm Dīnār Dam. In order to get money from them, he is reported to have stopped payment of the Jawāmik (monthly payment) to the Mamlūks who owned the Iqtạà's in that area (Ibn Iyās 1960).

Occasionally, funds collected for the irrigation dams (Muqarrar al-jusūr) were misappropriated by the sulțān and some high officials instead of being spent on maintenance and construction. Ibn Iyās (1960) reports several examples of corruption which occurred during his time. For instance, in JuneJuly 1511, Sulțān Qānșūh al-Ghawrī ordered Amīr Anșibāy to supervise the digging of a canal from al-Qanțara al-Jadīda to Qanātị al-Awz. The sultạn ordered the expenses to be taken from the Iqtạ ' holders and the peasants who would benefit from the project. About 50,000 Dīnārs were collected but only half this amount was spent on the construction, the surplus being taken to the Khazīna al-sharīfa (the sultạn's treasury).

Work on the irrigation dams was also imposed by corvee on the peasants and civilians. Mamlūk historians' document that men were often forced to work on repairing canals. For instance, al-Sayrafĩ mentions that Dawādār Yashbak compelled about 2,000 of the 'Āmma (civilians) to work on his dyke repair projects in August-September 1472 (Al-Șayrafī 1970).

\section{The Peasants and the Primitive Tools}

All of the tools used in agricultural activities in the Mamlūk kingdom, from planting to harvesting, were primitive. The plough (Mihrath), for instance, had no wheels. ${ }^{1}$ It was not designed to turn the soil and had only a shallow penetration. During this era, a pair of oxen could plough two-thirds or less of a Faddān a day in hard soil, and in soft soil they could plough about a Faddān (Girard 1942). In order to till and hoe the soil, the medieval peasants used the Mi 'wal (pickaxe) and Țūrya (axe or spade). They also used the Jarrāfa (rake or harrow) to level the ploughed land, to break up clods and to uproot weeds. Hassanein Rabie (1981) describes the Jarrāfa as being the rough branch of the acacia tree or the trunk of a palm tree with two rings fixed at one end on either side. The peasant would stand on it while a pair of draught animals pulled it along. Other tools such as the sickle to reap the crops, and agricultural techniques such as threshing, remain basically unchanged. Threshing by driving cows and bulls over the crops and winnowing by wooden forks, as well as other rudimentary techniques were similarly still in use until modern times.

\footnotetext{
${ }^{1}$ The French noble, Jean de Joinville, one of Saint Louis' companions during his Crusade to Egypt in the middle of the thirteen century, was astonished to see a plough with no wheels compared to what he had seen in his native Champagne (Duby 1968).
} 
One of the main economic problems afflicting mature empires is the absence of technological innovation. At a certain time, empires need to apply new technology so as to increase production. The Mamlūk empire is a case in point. Medieval Egyptian peasants still used the tools which were known and used in Pharaonic times and which are still used by peasants today without much change. Indeed, the agricultural implements described by Napoleon's scientists in Egypt were not significantly different from those depicted in Pharaonic wall paintings (Issawi 1974). Even at the present time, only slight progress has been made in the actual methods of agriculture, and consequently the peasants of today live much the same life as did serfs under the Pharaohs. "As a whole, " states Professor Shaler, "this land exhibits a singularly ancient adjustment of a people to their environment, one accomplished so early that there has been little change in their customs or numbers for at least four millennia" (Gemmill 1928).

Equally primitive techniques were used to irrigate the soil in order to produce summer crops. Water was transported to the fields in buckets or jars, tied to the necks of oxen or the sides of donkeys. Other methods of irrigation used by the medieval Egyptian peasants were the Nattāla and the Shadūf. In the Natțāa method, which was very ineffective, two men stood face to face, each holding two ropes to which was attached a wide, shallow, waterproof basket. These two men bent slightly towards the water, submerged the basket and filled it. Then they straightened their backs while turning to the field, thus raising the basket and emptying it into the mouth of the irrigation canal. Not many Faddāns could be irrigated in a day using this method. The Shadūf method was also extremely laborious. It was also slow and ineffectual and took most of the labouring population away from other work. Sometimes as many as four Shadūfs were needed, one above the other, to raise the water by stages from the Nile up to the fields above. All of these methods were inherited from an older time and some of them still continue to this day (Rabie 1981).

\section{The Peasants and the Natural Disasters}

Any discussion of the peasants in the Circassian Mamlūk period must discuss environmental issues and natural disasters since these regularly affected the agricultural sector leading to the destruction of crops and economic loss. The Mamlūk historians have preserved valuable data on the natural disasters during their times. For example, Aḥmad bin 'Alī al-Dalaj̄̄ alMișrī (d.1435), Al-Maqrīzī, Ibn Hajar al- 'Asqalānī (d.1449), Ibn Taghrī Bird̄̄ (d.1469), Al-Șayrafī (d.1495), 'Abd al-Bāsiṭ (d.1514), Ibn Iyās (d.1524) and the anonymous author of Nuzhat al-Nāzirīn, mention the environmental problems which the peasants had to deal with and describe how these problems played a significant role in their lives. Two categories of disasters are significant in the present discussion, namely climatic and biological. 


\section{Climatic Disasters}

Since Pharaonic times, Egypt has been witness to many severe weather disturbances. The Mamlūk period was no exception. References to the occurrences of drought, floods, violent rain or storms, hail and severe cold are readily found in the works of contemporary historians. The following are some descriptions of these climatic disasters in Egypt and the implications they had for agriculture and the lives of the rural dwellers.

\section{Droughts}

The consequences of drought are the loss of standing crops and shortage of the water needed by people and livestock. The impact on human life depends on the extent to which a particular society relies upon the vagaries of climate to raise crops and make a living. In the case of Egypt, drought (al-Jadb or alQaht) occurred when the level of the Nile was very low and not sufficient for cultivation. Indeed, the historians of the time remark that insufficient flooding of the Nile meant difficulty for the peasants. ${ }^{1}$

As noted earlier, cultivation could normally only be undertaken when the height of the Nile reached sixteen cubits. If the water of the Nile did not rise sufficiently to cover the soil, the peasants could not cultivate the land. A level of fourteen or fifteen cubits was too low and would leave many of the agricultural areas and basins dry. The result was that some of the arable lands were not sufficiently covered by water and thus could not be cultivated, and the price of commodities increased.

During the period with which we are concerned, insufficient rises of the Nile were reported in 1493,1496 and $1510 .^{2}$ Sometimes the Nile receded quickly after it had reached the level of sixteen cubits. This is reported to have happened in 1468, 1484, 1485, 1496, and 1505 (Ibn Iyās 1960).

\section{$\underline{\text { Floods }}$}

In contrast to the droughts mentioned by contemporary Mamlūk chroniclers, they also often refer to floods caused by the overflow of the Nile and unexpected heavy rainfall. Even though the Nile made life in Egypt possible with its water and alluvial deposits, the river might also be the cause of misfortune in the economic and agricultural life of the country. If the flood exceeded seventeen cubits, some areas became submerged under lakes for a long period and the proper time for sowing passed without taking place. Similarly, if the flood remained high for a long time it would not only cause damage to crops and cultivated lands but also to property.

During the period under consideration, there were damaging floods and rainstorms. In 1471, floods occurred and on 22 November 1469, violent rain caused the canals to overflow and damaged the houses. Heavy rain is also

\footnotetext{
${ }^{1}$ It is worth noting that the climate of Egypt was already dry, and that agriculture did not depend on the rainfall but rather on the yearly Nile flood. Modern research carried out by geographers and archaeologists shows that droughts sometimes took place in Egypt.

${ }^{2}$ According to Ibn Iyās (1960), the drought in this year affected various kinds of fruit, vegetables, flowers and grain.
} 
reported to have occurred in July-August 1474 and October-November 1481. In 1477, floods covered some areas including the province of al-Minyā and affected crops, dams, roads and houses. In 1497, another flood took place and caused damage and in 916/1510, heavy rains inundated the markets. On 28 March 1516, Ibn Iyās (1960) reports the occurrence of flash floods in Cairo because of heavy rain in Upper Egypt. These events necessarily caused considerable hardship for the peasants.

\section{Hailstorm and Severe Cold}

During the period under consideration, a hailstorm occurred in Damietta province in October-November 1492 and damaged the crops and killed livestock such as cattle and donkeys. According to Ibn Iyās (1960), each hailstone was the size of an ostrich egg. In December 1510, the provinces of alSharqiyya and al-Minūfiyya were hit by further hailstorms. The crops were destroyed, livestock perished and some of the peasants were injured.

Severe cold was another source of difficulty for Egyptian peasants. Frost would destroy the crops and even lead to the death of some animals. For example, in 1481 severe cold is reported to have killed some livestock in alGharbiyya. The same occurred in 1482 in Qarya Damrawa, this time ruining the crops. In December 1489-January 1490, freezing temperatures and frost killed some animals in Cairo. In 1492, crops were destroyed and some livestock perished in Damietta because of extreme cold. On another occasion in January-February 1494, cold weather and snow struck Alexandria. A similar disaster happened again in 510 in the al-Sharqiyya, al-Gharbiyya and alMinūfiyya provinces. This time crops were destroyed and some animals perished. Clearly, these events caused hardship to the peasants and affected agricultural production.

\section{Biological Disasters}

The contemporary chroniclers also inform us that the agricultural sector was similarly affected by biological disasters such as plagues, rat infestations, locusts, epizootics and crop blight.

\section{$\underline{\text { Plagues }}$}

The effect of the plague also can be seen in the countryside. A number of peasants died in the disaster and those who survived migrated to areas not affected by the plague. In the plague of 1476-1477 some villages were abandoned. According to Al-Sakhāwī (1995), in 1492 the plague killed a number of peasants in Siryāqūs and reduced a number of farmers to working in the farmyard at the Bilbays. On another occasion in 1513, the plague hit Asyūt and caused high mortality among the peasants. This disaster affected those members of the population who worked in the agricultural sector, especially in cultivation or harvesting. 
$\underline{\text { Rats }}$

Rats were another threat to the agricultural sector and an infestation could cause considerable damage to crops and harvests. Indeed, Ahmmad bin 'Alī alDalajī al-Mișrī (1904) explicitly mentions the trouble attacks of rats and mice caused for the peasants. Other accounts from primary sources show that infestations of rats destroyed plants, vineyards, fruits and other crops. Rats were not only responsible for damaging the crops in the fields, but also the harvest in the granaries.

\section{Epizootic}

Livestock and draft animals were understandably extremely important for Egyptian peasants. Indeed, they totally relied on these animals. The peasants ploughed using oxen or cattle, carried crops by donkey, and sometimes made their clothes from the wool of sheep and goats. They also bred some of these animals specifically for milk or meat production.

During the Mamlūk period, contemporary sources mention the threat of an epizootic to these animals which affected the life of the peasants and agricultural activities. The consequences of animal disease can be seen in that one nobleman who owned 1,021 cattle before the outbreak of the disease, lost 1,003 of them. Similar occurrences took place in 1491-1492 and 1509. As a result, the price of cattle increased as did the cost of hiring animals for ploughing (Ibn Iyās 1960). The scarcity of cattle also led to a scarcity of meat.

\section{Worms and Caterpillars}

Attacks of worms also contributed to the devastation of crops and some villages lost half of their yield because of them. On several occasions crops such as clover, wheat and berseem were affected. During the period under consideration, similar occurrences took place in 1485 and 1486. The usual result was that the peasants faced hardship because of losses and an increase in clover prices, this plant being the basic fodder for cattle in Egypt (Al-Sakhāwī n.d.).

\section{Conclusion}

In brief, it is no exaggeration to say that the peasants at the end of the Mamlūk period were treated very harshly and suffered from financial burdens, exploitation, psychological pressure and tyranny. In this, the administrative apparatus abused its authority and resorted to illegal methods in the treatment of the peasants. The inevitable consequence of all this was considerable damage to the agricultural sector in Egypt. Indeed, some of the Muqtạ̄ s stried to rescue their lands by forbidding the peasants from leaving them. This migration resulted in a lack of labourers which in turn led to some cultivated areas being neglected and the necessary consequences for agricultural production.

In spite of this, and because there was no alternative, the medieval peasants in Egypt had to produce crops for their Muqțā's and for their own 
consumption. With these primitive implements they ploughed and tilled the soil. Using the ancient methods of artificial irrigation, they irrigated the land and they harvested their crops with sickles. They had no defences against disasters such as crop blight, rats or drought. The consequence of using these primitive tools and old methods of irrigation was that agricultural production was always limited at a time when the state needed more products for its own consumption and for trade.

\section{Acknowledgments}

Research for this study was supported by a grant from The National University of Malaysia (Grant No. DPP-2014-068).

\section{References}

Al-Asad» $\mathrm{Mu}^{-}$ammad b. $\mathrm{Mu}^{-}$ammad b. Khal»1 (1968) Al-tays»r wa al-i'tib«r wa altahr»r wa al-ikhtib«r f»m« yajibu min ${ }^{-}$usn al-adb»r wa al-ta-arruf wa alikhtiy $r$, [Treatise on administrative and financial reform]. 'Abd al-Q $\ll$ dir $\mathrm{A}^{-}$mad ${ }^{2}$ ulaym«t, Dar al-Fikr al-'Arabi (Ed). n.p.

Al-Makhzūmī Abū al-Ḥasan 'Alī bin 'Uthmān (1986) Kitāb al-minhāj fì 'ilm kharaj mișr [Book on method of Egyptian kharaj]. Claude Cahen (Ed) Cairo: Institut Francais d'Archeologie Orientale.

Al-Maqr»Z» Taq» al-D»n A $\mathrm{A}^{-} \operatorname{mad} \mathrm{b}$. 'Al» (1940) Igh«that al-umma bi kashf alghumma [Helping the nation by examining causes of distress]. $\mathrm{Mu}^{-}$ammad $\mathrm{Mu} \cdot{ }^{3} \mathrm{af} \ll$ Ziy«da \& Jam«1 al-D»n al-Shayy«l (Eds). Cairo: Lajnat al-Ta'l»f wa alTarjama wa al-Nashr.

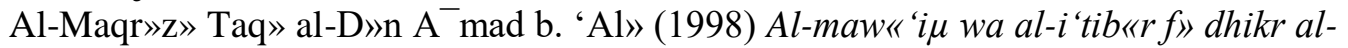
$k h i^{3} a^{3}$ wa al- ${ }^{a}$ th $r$ al-ma' $r-f$ bi al-khi ${ }^{3} a^{3}$ al-maqr»ziyya [Topographic and historical description of Egypt]. $\mathrm{Mu}^{-}{ }^{-}$mmad Zaynhum, Mad» ${ }^{-} \mathrm{a}$ al-Sharq«wi (Eds) 1. Cairo: Maktabat Madb-l».

Al-Mișrī Aḥmad bin 'Alī al-Dalajī (1904) al-Falak wa-l-maflūkūn [Misfortune and unfortunate]. Cairo: n.p.

Al-Nuwayrī Shihāb al-Dīn Aḥmad bin 'Abd al-Wahhāb (1931) Nihāyat al-arab fì funūn al-adab [The aim of the intelligent in the art of letters] 8. Cairo: Dār alKutub al-Mișriyya.

Al-Qalqashandī, Aḥmad bin 'Alī (1987) Subh al-a shā fí șinā at al-inshā [The dawn of the blind]. Muhammad Ḥusayn Shams al-Dīn (Ed) 3, Beirut: Dār al-Kutub al'Ilmiyya.

Al-Sakhāwī (1995) Waj̄̄z al-kalām fì al-dhayl 'alā duwal al-islām [A brief speech of book on Islamic kingdoms] 3. Basshār 'Awwāẹ Ma'rūf, Mu'assasat al-Risāla (Ed). Beirut.

Al-Sakhāwī (n.d.) al-Tibr al-masbūq fì dhayl al-sulūk [The gold dust of the kitab alsuluk], Cairo: Maktabat al-Kulliyyāt al-Azhariyya.

Al-Ṣayrafī 'Alī bin Dāwud al-Jawharī (1970) Inbā' al-hașr bi-abnā' al-'aṣr [Informing the lion about scions of the age], Hasan Habashī (Ed). Cairo: Maṭa' at al-Madanī. 
Al-Ṭurkhān Ibrāhīm 'Alī al-Nuẓum (1968) al-Iqtạ iyya fì al-sharq al-awsat fí al-' 'uṣūr al-wustạ [al-Iqțā' in the middle east during the medieval ages]. Cairo: Dār alKitāb al-'Arabī.

Cooper RS (1977) Agriculture in Egypt, 640-1800. In Bertold Spuler (Ed), Handbuch der orientalistik, Leiden: E. J. Brill: 188-204.

Duby G (1968) Rural Economy and Country Life in the Medieval West. trans. Cynthia Postan. London: Arnold.

Gemmill PF (1928) Egypt is the Nile. Economic Geography 4: 295-312.

Girard PS (1942) al-Ahwāl al-zirā 'iyya fì al-quṭr al-mīṣrī athnā' hamlat nābuliyūn bunaparta [The situation of agriculture in Egypt during the Napoléon Bonaparte campaign]. trans. Yūsuf al-Naḥhās \& Khalīl Mițrān, Cairo: n.p.

Ibn Iy«s Mu' ammad b. A' mad (1960) Bad «'i al-zuh-r f» waq«'i al-duh-r [Marvels blossoming among incidents of the epochs]. $\mathrm{Mu}^{-}$ammad Mușaf $«$ (Ed) 3-5. Cairo: $\mathrm{D} \ll \mathrm{r} \mathrm{I}^{-} \mathrm{y}$ «' al-Kutub al-'Arabiyya.

Ibn Taghrī Birdī (1932) Hawādith al-duhūr fì madā al-ayyām wa-l-shuhūr [Episodes of the epochs which pass in the days and months]. William Popper (Ed). California: University of California Press.

Ibn Ṭūlūn, Shams al-Dīn Muhammad bin 'Alī al-Ṣāliḥ̂̄ al-Dimashqī (1973) I'lām alwarā bi-man waliya nā'iba min al-atrāk bi-dimashq al-shām al-kubrā aw tārīkh al-shām min qiyām dawlat al-mamālìk fì mișr ilā șadr al- 'ahd al- 'uthmānn̄ [The history of Sham from the establishment of Mamluk kingdom to the start of the Ottoman period]. 'Abd al-'Azịm Hāāmid Khaț̣āb (ed). Cairo: Maṭba at Jāmi'at 'Ayn Shams.

Issawi C (1974) Economic History and the Middle East. Middle East Studies Association Bulletin 8: 1-8.

Nāṣir 'Āmir Najīb Mūsā (2003) al-Hayāh al-iqtișādiyya fì miṣr fì al- 'aṣr al-mamlūk̄̄ [The economic life in Egypt during the Mamlūk period]. Amman: Dār al-Shurūq li-Nashr wa al-Tawzī'.

Rabie H (1981) Some Technical Aspects of Agriculture in Medieval Egypt. In AL Udovitch (Ed) The Islamic middle east - 700-1900. Princeton: Darwin: 59-90. 